\title{
20. Gotong royong and the role of community in Indonesia
}

Adrian Perkasa

'We are tired with DraSu, all we need is gotong royong!' This statement came from Husin Ghozali, alias Cak Conk, who was the owner of Warung Kopi (coffee shop or warkop) Pitu Likur in Surabaya, Indonesia. His coffee shop went viral in social media in the last week of July 2020, or the beginning of the new school year in Indonesia. The Indonesian government decided to conduct online learning, or School from Home (SFH), in all levels of education, from elementary to high school, owing to the COVID-ı9 outbreak. However, many students' parents were unhappy with this decision, especially in many households in the kampungs (neighbourhoods) of Surabaya. They felt it brought more difficulties to their families, who were already struggling very hard to cope with the new situation. Then, Cak Conk initiated a plan to help many students in his kampung. He invited students to use the Wi-Fi in his coffee shop during SFH (see Figure 20.I). Not only free access to the internet; he also provided a glass of tea or milk for the students who spent their school day there.

Unfortunately, the municipal government of Surabaya complained about Cak Conk's initiative. An official from the Dinas Pendidikan (Education Agency) of Surabaya warned students to avoid public spaces such as his warkop to prevent increasing numbers of COVID-I9 cases. In line with this complaint, several members of the Surabaya Parliament also criticised the warkop. They urged the students to stay at home as regulated previously by the government. According to them, Surabaya's municipality would provide free internet in several public spaces in the neighbourhood, such as Balai $R W$ (the neighbourhood hall). However, by mid-August 2020, this plan had remained on paper (Kholisdinuka 2020). Moreover, the students still came to Warkop Pitu

How to cite this book chapter:

Perkasa, Adrian. 2022. 'Gotong royong and the role of community in Indonesia'. In: Shin, Hyun Bang; Mckenzie, Murray; and Oh, Do Young (eds) COVID-I9 in Southeast Asia: Insights for a post-pandemic world. London: LSE Press, pp. 228-238. DOI: https://doi.org/IO.3I389/lsepress.cov.t License: CC BY 4.०. 
Figure 20.1. Free Wi-Fi for online schooling ... Free: a cup of tea

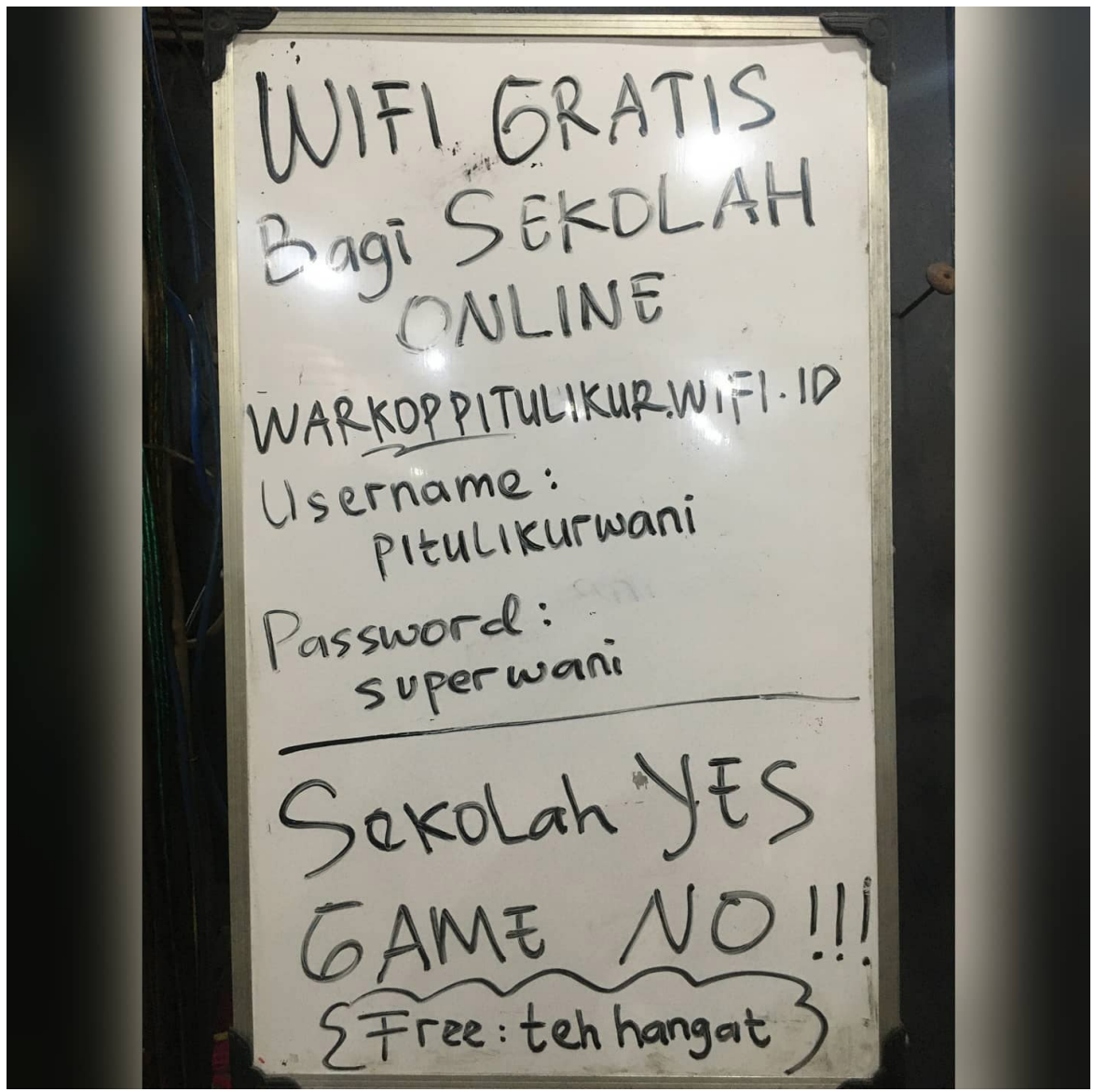

Source: Reproduced with permission of the photographer.

Likur every morning to attend school online. Cak Conk explained to me on the phone at the end of July:

Actually, I don't have any intention to promote my business. I only heard many parents of my son's friends in the school face difficulties in providing internet for their children. Thus, I just quickly responded by open [sic] my warkop for them.

According to him, kampung people were tired of the failure of the government to minimise the pandemic's effects on their everyday lives (interview, 26 July 2020). Surabaya, the second biggest city in Indonesia and the capital of East Java province, had become the epicentre of the COVID-I9 outbreak in this province. Moreover, this situation was 
worsening because of the bitter relationship between the mayor of Surabaya, Tri Rismaharini, and the governor of East Java, Khofifah Indar Parawansa. Many people in Surabaya, including Cak Conk, had a particular term referring to this relation: Drama Surabaya (Surabaya Drama) or DraSu.

This term was derived from Drama Korea (Korean Drama/K-Drama) or DraKor, which had recently become popular in many parts of the world. The first publicly acrimonious dispute between the two figures was over the planning of Surabaya to limit the mobility of people entering the city. The governor refused this plan because, according to her, large-scale social restrictions had been implemented under the authority of the regional and national governments. A few weeks later, they became involved in hostilities again after Tri Rismaharini told the media that the increasing COVID-I9 cases in Surabaya were because many new patients in Surabaya hospitals had come from other towns in East Java. The two of them were engaged in conflict over two mobile polymerase chain reaction (PCR) test labs, which had been loaned from the Badan Penanggulangan Bencana Nasional (National Mitigation Disaster Agency) (Syambudi 2020). In early August 2020, the governor denied the mayor's claim of a decreasing number of COVID-I9 cases in Surabaya.

The political rivalry between these two leaders also affected the pandemic's management, especially in hospitals and other healthcare facilities. According to Donny, ${ }^{\mathrm{I}}$ a doctor at Surabaya's Dr Soetomo Hospital, many difficulties emerged in handling the COVID-I9 pandemic because of that rivalry (interview, 26 July 2020). The first and foremost problem, according to him, was that there was a lack of coordination between healthcare facilities managed by the municipality of Surabaya and those managed by the province of East Java. Dr Soetomo Hospital was the COVID-I9 referral centre in the Surabaya region operated by the province of East Java. As soon as the COVID-I9 outbreak began in Surabaya, many new patients sent directly to this hospital from Surabaya's healthcare facilities bypassed national and regional handling procedures for COVID-I9. As a result, the hospital became an epicentre for the virus's spread. The spokesman for Surabaya's disease task force publicly stated several times, however, that the situation in Surabaya was under control (Widianto and Beo da Costa 2020a).

The Ikatan Dokter Indonesia (Indonesian Medical Association) admitted that healthcare workers had felt overwhelmed by the high number of patients and increasing workloads due to the government's 
pernicious management. Arguably, the world's highest rate of deaths of healthcare workers was in Indonesia (Barker, Walden, and Souisa 2020). Many medics in Surabaya were reportedly infected by the virus. 'It's like a vicious cycle, and the one blames another party and vice versa. The municipal and provincial governments should work together to protect their people. We need gotong royong,' Donny stressed to me. Again, there was another person who emphasised the importance of gotong royong, loosely translatable as 'communal or neighbourly help', to deal with the pandemic.

People practise gotong royong in everyday life and communal activities, from family celebrations such as weddings or engagements to the celebration of religious feasts and national days. It is also not uncommon for kampung people in urban areas like Surabaya to still practise gotong royong. The case of Cak Conk and his warkop has been the best example of how gotong royong has been relevant during the pandemic. In previous studies, scholars such as Bowen (I986), Guinness (I986), and Sullivan (I986) have argued that gotong royong is a construction from the state, rather than originally embedded in the Indonesian community. Even though this kind of mutual assistance reflects genuine indigenous notions of moral obligations and generalised reciprocity, it has been argued that it has been reworked by the state to become a cultural-ideological instrument for the mobilisation of village labour (Bowen I986, pp.545-546). Suwignyo (2019, p.407) traced the initial concept of gotong royong to the Dutch colonial period and its further development under Japanese occupation and in post-independence Indonesia. According to his research, every government from the I940s to the I990s promoted gotong royong extensively as a signifier of collective identity. He concluded that gotong royong became a form of social engineering and an ingenious linguistic strategy by which elites orchestrated control over citizenship-making.

Nevertheless, the aspirations of Cak Conk and Doctor Donny in Surabaya seemingly contradicted such scholarly arguments. Rather than the state promoting gotong royong, the people were urging their government to act with gotong royong when facing troubled times during the pandemic. Or, can it be said that Cak Conk's initiative for gotong royong was only a particular case or even an exceptional phenomenon?

A recent survey by LaporCOVID-I9 and the Social Resilience Lab at Nanyang Technological University showed that the majority of people in Surabaya tended to underestimate the risk of being infected by coronavirus. The economic and social situations also had a significant 
impact on the lesser perception of risk (LaporCOVID-I9 2020). Thus, the kampung people who worked as daily labourers or ran a small warung like Cak Conk contributed heavily to this lesser perception of risk. Another scholar in Surabaya, Windhu Purnomo, also stressed the similar argument that most of the people in Surabaya only prioritised their economic interests in the traditional market and public spaces (Larasati 2020). These arguments were in line with the state perspective that often blamed people as a main cause of the high number of COVID-ı9 cases in Surabaya (Meilisa 2020).

To get a broader picture and understand the situation in Surabaya, I am turning my attention to look at bottom-up responses from other kampungs. Despite many limitations during this time, I tried to conduct fieldwork in online environments. I interviewed several kampung residents in Surabaya whom I had known before, including Cak Conk and Doctor Donny, via WhatsApp video calls. The first kampung I decided to scrutinise was Kampung Peneleh (see Figures 20.2 and 20.3). I have had a long and intensive relationship with the residents of this kampung for more than a decade. I have also been working as a local principal investigator for the Southeast Asian Neighbourhood Network (SEANNET) in Kampung Peneleh. I worked with several residents of Kampung Peneleh - including Obet, who assisted me with writing field notes from March to August 2020.

In the early period of the outbreak, the kampung situation seemed to confirm the results of the LaporCOVID-I9 survey. There was a disagreement within the kampung in the adoption of new health protocols. A group of youths in a neighbourhood association promoted new hygienic attitudes by spraying disinfectant gas throughout the kampung and surrounding areas. However, not everyone, including several elders in the kampung, agreed with their initiative. The situation quickly escalated to a physical conflict between a youth neighbourhood association and other groups in the kampung. Eventually, after several heads of Rukun Tetangga (RT; the Neighbourhood Associations) mediated, the conflict subsided.

Perhaps one can quickly assess that the above situation displayed how many groups in the community resisted new health protocols. Nevertheless, the root of the dispute within Kampung Peneleh was not about resistance to health protocols after an outbreak. The first and foremost reason why many groups in Kampung Peneleh rejected the plan of fogging or spraying disinfectant was because this activity was fully sponsored by a political candidate who would be running in a mayoral election at the end of the year. This candidate was promoted 
Figure 20.2. An entrance to Kampung Peneleh with notification banners to obey health protocols

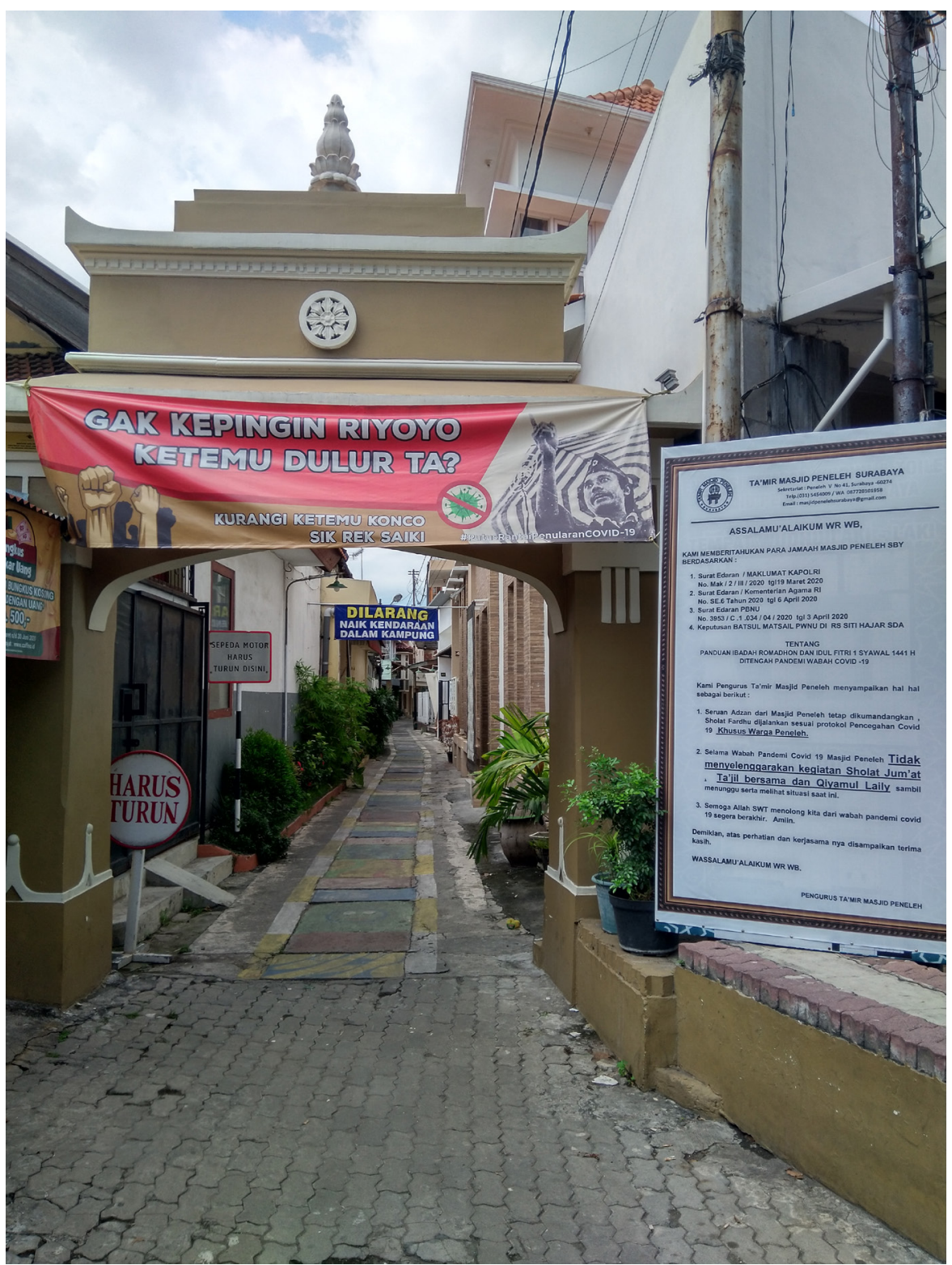

Source: Image taken by Obet on I 3 May 2020. Reproduced with permission of the photographer.

by the coalition of political parties who opposed the incumbent mayor from Surabaya. However, the heads of RT in Kampung Peneleh decided only to follow official protocols from the government. 
Figure 20.3. Eid prayer in Kampung Peneleh during the pandemic

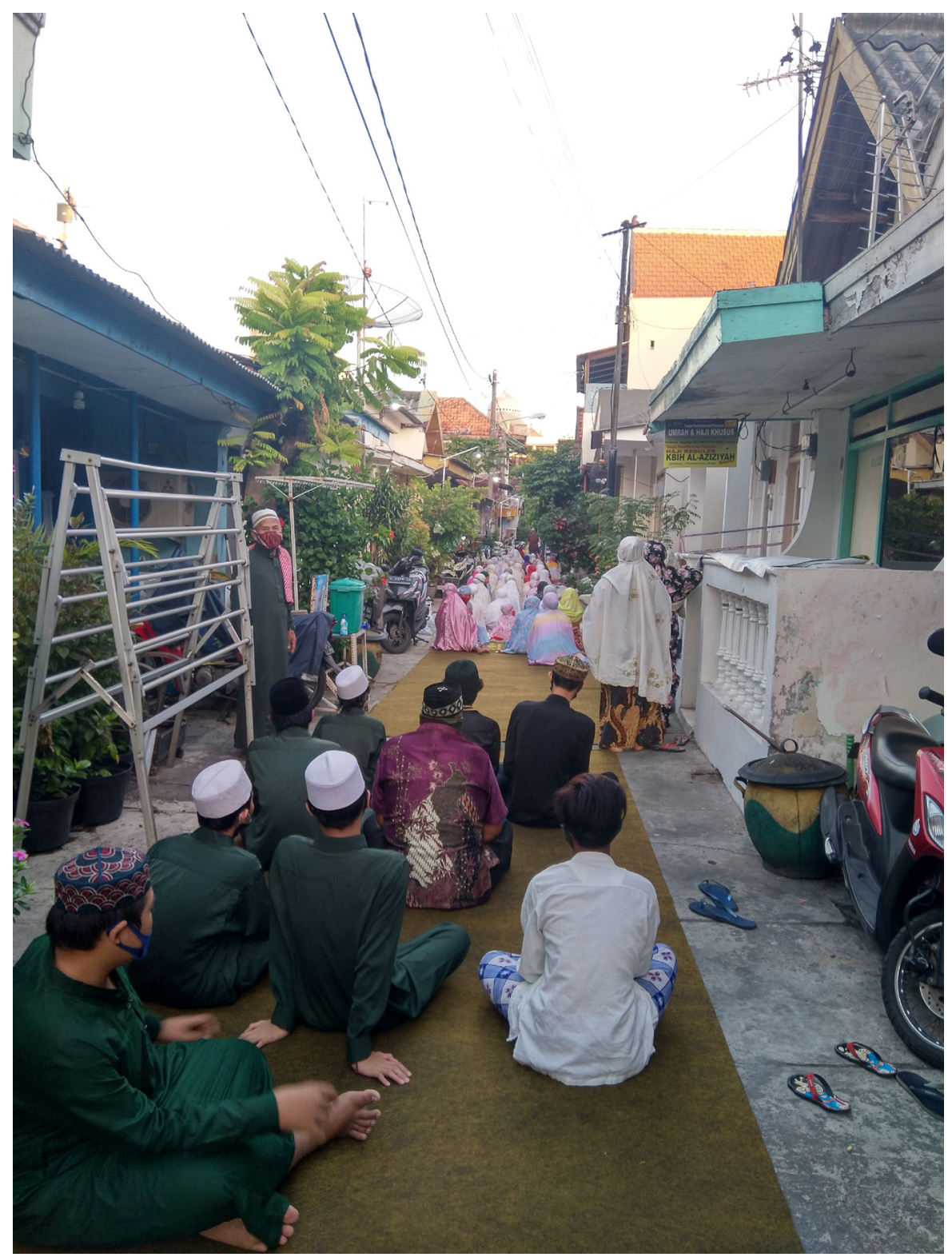

Source: Image taken by Obet on 3 I July 2020. Reproduced with permission of the photographer.

Indeed, there was further resistance to obey new health protocols in Kampung Peneleh. Several kyai (Islamic leaders) and ustadz (Islamic teachers) refused a health protocol that requested the closure of the mosque until further notice. According to them, it was heretical to fear 
the threat of a virus; all Muslims should only fear God. Moreover, the situation became more difficult because the first request from the government coincided with Ramadan, a month full of fasting and praying for Muslims. There is a significant and historical mosque in Kampung Peneleh called Masjid Jamik (Grand Mosque). Before the COVID-I9 outbreak, this place was a centre of religious activities during Ramadan not only for people in Kampung Peneleh but also for people from surrounding neighbourhoods. As a consequence, the kyai and ustadz declined the request of the official health protocols. They were still doing many activities as they usually did in Ramadan before the pandemic.

Later there was a circular letter dated 3 April 2020 from the Nahdlatul Ulama, the biggest Islamic organisation in Indonesia, in response to the COVID-I9 outbreak. They issued a decision to slow the spread of coronavirus by avoiding any activities of meeting and gathering of Muslims in large numbers. It called for the implementation of worship during Ramadan, usually done together with the congregation in mosques or other praying halls, to be held at home. Other activities relating to the celebration of the Eid al-Fitr feast after Ramadan were also to defer to the provisions and policies of social restrictions and maintaining physical distance as determined by the government's official health protocols (Surat Edaran PB Nahdlatul Ulama 2020). Likewise, Muhammadiyah, another prominent Islamic organisation in Indonesia, had released a similar statement several days earlier (Surat Edaran PP Muhammadiyah 2020). Although these instructions were not directly implemented in Peneleh, the kyai and ustadz gradually started following it. Moreover, these figures also participated in promoting the government's instruction for people to stay at home for Eid al-Fitr and not going back to their respective regions or mudik. They did it through gotong royong with other kampung residences, including those who professed other religions such as Christianity, Hinduism, and Confucianism. ${ }^{2}$

Another case came from Kampung Pabean, where the biggest traditional market in Surabaya is located. As expected by previously mentioned scholars like Windhu Purnomo, indeed, many daily workers in that market were not obeying health protocols. However, it was only a slice of reality in the market and the kampung, and it was incomplete. Sahib, who was living in this kampung and was also a caretaker of the neighbourhood association there, told me another story. Together with the association, he always reminded everyone in the market and the neighbourhood to follow health protocols. In addition, they provided daily workers in the market with a free mask every day. Furthermore, 
the neighbourhood association of Kampung Pabean was taking care of the poor people who became infected by the virus and were required to self-quarantine at home. They voluntarily supplied provisions to them during the quarantine: Sahib thus argued that 'we should gotong royong to take care of ourselves' (interview, 27 July 2020).

\section{Conclusions}

There were many bottom-up initiatives led by the people of Surabaya's kampungs, but they have been neglected by most scholars. Instead of endorsing these people's initiatives, some scholars have only painted the same picture as the state - a perspective that has seen people's lack of awareness as the leading cause of the increasing numbers of COVID-I9 cases in Surabaya. People like Cak Conk and the residents of Kampung Peneleh and Kampung Pabean have effectively incorporated the concept of gotong royong as a strategy to face the pandemic. They have urged and challenge the government, especially the municipality of Surabaya and the East Java provincial government, to set aside political enmity and use gotong royong to prevent further adverse effects from COVID-r9.

As Springer (2020, p.II4) has stated, in this challenging moment, people can gather, depending not upon the state and the command of any authority but on their collectivity. As one could see in the people's gotong royong, collectivity was vital not only during this time but also for their future as urban dwellers and Indonesian citizens. However, Indonesia's crisis went from bad to worse. Indonesia failed to bring the pandemic under control after March 2020: as of December 2020, there were 563,680 confirmed cases and I7,479 confirmed fatalities, plus another nearly 70,000 suspected cases. It has had by far the most extensive caseload and death toll in Southeast Asia, and the data showed that at the time of writing the situation was intensifying (Widianto and Beo da Costa 2020b). Following Harari's (2020) argument, today's civilisation faces an acute crisis, not only because of coronavirus but also because of the lack of trust among humans. People must trust science, and citizens need to trust public authorities. In addition to that, the state should show that its citizens can trust them. As with scientists, citizens, and public officials, trust and good faith prevail when people can rely on each other to uphold their commitments. Instead of requiring obedience, public authorities can appeal to common goals so that everyone can appreciate the needs that underlie a pledge or policy. 


\section{Notes}

I. I have changed the names of all informants except Cak Conk and his warkop.

2. Indonesia's Ministry of Religion recognised Confucianism as one of six official religions in Indonesia.

\section{References}

Barker, Anne; Walden, Max; and Souisa, Hellena. (2020). 'In five days, Dea lost half her family to coronavirus. Now she's fighting COVID-I9 alone in isolation'. ABC News, 26 June. https://perma.cc/D7JS-Z933 [Last accessed 3I July 2020].

Bowen, John. (I986). 'On the political construction of tradition: Gotong Royong in Indonesia'. The Journal of Asian Studies, vol. 45, no. 3, pp. 545-56r. https://doi.org/I0.2307/2056530

Guinness, Patrick. (1986). Harmony and Hierarchy in a Javanese Kampung. Singapore: Oxford University Press.

Harari, Yuval Noah. (2020). 'In the battle against coronavirus, humanity lacks leadership'. Time, I 5 March. https://perma.cc/VC9D-L4DC [Last accessed 9 January 202I].

Kholisdinuka, Alfi. (2020). 'DPRD Surabaya Desak Pemkot Tambah Subsidi Internet Untuk Anak Miskin'. Detik News, I3 August. https://perma.cc 16CHQ-7VBS [Last accessed 3 September 2020].

LaporCOVID-19. (2020). Persepsi Risiko Surabaya. https://perma.cc/PQ5M $-\mathrm{SV}_{3} \mathrm{R}$ [Last accessed 3 September 2020].

Larasati, Aziza. (2020). 'Penyebab Jatim Pusat COVID-ı9 Kurangnya Disiplin dan Kesadaran Masyarakat'. Mata-Mata Politik News, 3 July. https://perma .cc/MJW 4-2 $\mathrm{PY}_{4}$ [Last accessed 3 September 2020].

Meilisa, Hilda. (2020). 'Khofifah Sebut Tingkat Kepatuhan Protokol COVID-r9 Surabaya Raya Rendah'. Detik News, 24 June. https://perma.cc 19HBM-9RTK [Last accessed 3 September 2020].

Springer, Simon. (2020). 'Caring geographies: The COVID-I9 interregnum and a return to mutual aid'. Dialogues in Human Geography, vol. ıо, no. 2, pp. I I 2-I I 5. https://doi.org./IO.I I 77/204382062093 I 277

Sullivan, John. (I986). 'Kampung and state: The role of government in the development of urban community in Yogyakarta'. Indonesia, vol. 4I, pp. $63-88$. https://doi.org/I0.2307/3351036 
Suwignyo, Agus. (2019). 'Gotong royong as social citizenship in Indonesia, I940s to I990s'. Journal of Southeast Asian Studies, vol. 50, no. 3, pp. 387-408. https://doi.org/IO.IOI7/S00224634I9000407

Syambudi, Irwan. (2020). 'Perseteruan Risma Dan Khofifah Di Zona Merah Corona'. Tirto.ID, 9 June. https://perma.cc/3 NMK-LYFV [Last accessed I August 2020].

Warkop Pitu Likur. (2020a). 'Hari pertama adek2 kita lagi semangat belajar daring memanfaatkan wifi di warkop PituLikur secara gratis dan free teh hangat juga'. Twitter, 20 July. https://perma.cc/XL62-37 H9 [Last accessed 26 July 2020]

Warkop Pitu Likur. (2020b). 'Tetap semangat belajar adek2, walaupun dgn keterbatasan dimasa pandemi ini'. Twitter, 2 I July. [Last accessed 26 July 2020]. https://perma.cc/D96N-X6QF[Last accessed 26 July 2020].

Widianto, Stanley; and Beo Da Costa, Agustinus. (2020a). 'Coronavirus patients flood hospitals in Indonesia's second-largest city’. Reuters, 28 May. https://perma.cc/7HV6-36GW [Last accessed I August 2020].

Widianto, Stanley; and Beo Da Costa, Agustinus. (2020b). 'Death of senior doctor rings alarm bells in pandemic-struck Indonesia'. Reuters, 3 December. https://perma.cc/G2UT-G6WA [Last accessed 9 January 202I]. 